\title{
Case Report and Review of the Literature
}

\section{Giant Abdominal Mass: Papillary Renal Cell Carcinoma with Metastases to the Bladder, Omentum and Perigastric Tissue}

\author{
Miguel Augusto Martins Pereira $^{1 *}$, Roger Jordan Freitas ${ }^{1}$, Lucas Natã Lessa Silva ${ }^{1}$, Rafael Catelli ${ }^{2}$ and Hye Chung \\ Kang $^{3}$
}

${ }^{l}$ Medical Undergraduate, Medical School of Fluminense Federal University, Niterói, Rio de Janeiro, Brazil

${ }^{2}$ Pathology Resident, Medical School of Fluminense Federal University, Niterói, Rio de Janeiro, Brazil

${ }^{3}$ Professor, Fluminense Federal University, Department of Pathology, Niterói, Rio de Janeiro, Brazil

\begin{tabular}{l} 
A R T I C L E I N F O \\
\hline Article history: \\
Received: 18 April, 2020 \\
Accepted: 29 April, 2020 \\
Published: 1 May, 2020 \\
\hline Keywords: \\
Carcinoma \\
neoplasms metastasis \\
urinary bladder \\
cells \\
case reports \\
omentum \\
kidney neoplasms
\end{tabular}

\begin{abstract}
A B S T R ACT
Papillary renal cell carcinoma is an uncommon malignant tumor, which rarely metastases to the bladder and/or omentum. We report the case of a 71-year-old woman with macrohematuria for two years and a large mass on the right flank. Thus, we present a brief review of the literature regarding the classification, clinical manifestations, diagnosis, immunohistochemical profile, and treatment of this neoplasm. Special attention was given to the role of immunohistochemistry, which was decisive for the determination of multiple metastases, as well as the study by imaging exams, which defined the best surgical approach.
\end{abstract}

(C) 2020 Miguel Augusto Pereira. Hosting by Science Repository.

\section{Introduction}

Papillary renal cell carcinoma (PRCC) is a malignant tumor of the renal parenchyma with papillary architecture [1]. It is the second most common subtype (10-15\% incidence) among the five renal cell carcinomas (RCC) subtypes described in the Heidelberg classification [2-4]. Regarding its origin, it is essential to emphasize that the PRCC can be sporadic or hereditary [5]. The PRCC was recognized, approximately two decades ago, as a different entity in the Heidelberg's classification. It was Kovacs who proposed to consider it an entity separate from renal neoplasms and suggested that a renal tumor should be classified as papillary if at least $75 \%$ consisted of papillary structures $[6,7]$.

The PRCC, as well as the RCC, in general, may or may not have clinical manifestations, which are quite variable. There is a classic triad composed of hematuria, palpable abdominal mass, and flank pain, however, present only in 6 to $10 \%$ of cases, generally the more severe ones [1]. Nonspecific symptoms, such as fever, fatigue, and weight loss, are also described [8]. Besides, it is possible to find endocrinological syndromes, such as Cushing's Syndrome, hypercalcemia, polycythemia, mainly due to hypersecretion of erythropoietin by cancer cells [8-10]. Also, several other non-endocrinological syndromes may be associated, for example, anemia, systemic arterial hypertension, liver dysfunction, vasculopathy, and amyloidosis [9].

According to Robson's modification of the Flocks and Kadesky staging system, RCCs, in general, can be classified into four stages. Stage I consists of those cases in which the renal capsule contains the tumor. In stage II, the tumor invades the perirenal fat but is held by the Gerota Fascia. In stage III, the tumor is found affecting the region's lymph nodes and / or the vena cava and renal veins. Finally, stage IV is one in which

${ }^{*}$ Correspondence to: Miguel Augusto Pereira, Department of Pathology, Clinical Hematology, Marquês do Paraná Avenue, 303, Niterói, RJ, 24033 900, Brazil; Tel: 5521992500199; E-mail: mappereira@icloud.com.br

(C) 2020 Miguel Augusto Pereira. This is an open-access article distributed under the terms of the Creative Commons Attribution License, which permits unrestricted use, distribution, and reproduction in any medium, provided the original author and source are credited. Hosting by Science Repository. http://dx.doi.org/10.31487/j.JSO.2020.03.01 
the tumor affects other organs and presents metastasis from a long distance [11].

According to Robson's staging classification, computerized tomography (CT) or magnetic resonance imaging is necessary [5]. In contrast, the classification of these carcinomas according to the TNM system establishes stage 1, which varies from $\mathrm{T} 1$ at $\mathrm{T} 2$, it is $\mathrm{N} 0$ and $\mathrm{M} 0$, stage 2, T3a, N0 and M0, stage 3 which varies from T3b to T3c, from N1 to $\mathrm{N} 3$ and is M0; finally, stage 4 is classified as T4 and M1.12 There is also one of the classifications (Delahunt) of this carcinoma in terms of morphology, in types 1 and 2, with type 1 having the highest prevalence, corresponding to $73 \%$ of cases $[5,12]$.

\section{Case Presentation}

A 71-year-old female with a large painless mass on right flank, macroscopic hematuria for two years and prior history of hypertension and deep venous thrombosis. A CT showed a large heterogeneous mass, predominantly cystic with septate solid areas of post-contrast enhancement. The patient underwent a radical nephrectomy. The pathological examination revealed a 4,950g kidney measuring $28,5 \mathrm{x}$ $19,5 \times 16,0 \mathrm{~cm}$. The diagnosis was compatible with papillary renal cell carcinoma (PRCC) pT2b, pN0, type 2 of Delahunt, nuclear grade 2, occupying the entire renal parenchyma, without vascular invasion and impairment of the capsule [1]. It was classified as Flocks and Kadesky II since the Gerota's fascia restricted it. Immunohistochemical analysis demonstrated positivity for racemase and vimentin, also negativity for RCC Ma and p63. After six months, the patient reported resumption of hematuria. A CT exam showed a $3.2 \times 3.1 \mathrm{~cm}$ vegetation inside the bladder. Thus, transurethral resection of the bladder was performed. Histopathological examination was compatible with the same profile of PRCC. Therefore, it was considered a metastasis. After a six-month follow-up, were found new tumors, in the omentum and perigastric region, compatibles with the same PRRC.

\section{Discussion}

The PRCC can be divided into types 1 and 2. PRCC type 1 is characterized by thin papillae and tubular structures covered by a single layer of small cells, containing cytoplasm ranging from amphiphilic to basophilic, with an oval nucleus, small, hyperchromatic and uniform [5, 13]. Generally, PRCC type 1 presents as stages I or II of the disease and has a favorable prognosis [13]. There is also a type of hereditary carcinoma classified as PRCC type 1, called Hereditary Papillar Renal Cell type 1 (HPRCT), whose pathogenesis is associated with an inherited mutation of the MET protooncogene. In contrast, the mutation in this gene is more uncommon in sporadic cases of papillary carcinoma $[1,2$, $10,14]$.

In contrast, type 2 is more heterogeneous, being characterized by papillae covered by a thick layer of cells with eosinophilic cytoplasms, with a granular aspect, with spherical, pseudo-stratified nuclei, and with a prominent nucleolus, associated with the formation of necrosis areas $[5,15,16]$. This second type is frequently associated with aggressive stage III and IV tumors and, therefore, is associated with a worse prognosis $[15,16]$. Still regarding type 2 , there is a carcinoma of a hereditary cause, called Hereditary renal leiomyoma cell carcinoma
(HLRCC), related to a mutation of the 1q42-43 gene, which encodes the fumarate hydratase enzyme $[1,17]$. In our case, the patient developed a PRCC type 2, according to the Delahunt classification and, before the open radical nephrectomy, the tumor was classified as stage II by Flocks and Kadesky since the Gerota Fascia restricted it. Imaging studies, especially CT, allows the identification of invasion to lymph chains or other neighboring structures, soon to be staged, and in the case presented, it helped to delimit the size of the lesion and define a surgical approach [17]. After all, the situation calls attention at first sight due to the size of the tumor, reaching almost $30 \mathrm{~cm}$ in the longest axis, and most cases of PRCC have their dimensions contained between $5 \mathrm{~cm}$ to $10 \mathrm{~cm}$. The immunohistochemical profile of PRCC is quite varied. For diagnostic purposes, it presents a strong expression of alpha-methyl acyl-coenzyme A racemase (AMACR), CD10, vimentin, as well as RCC Ma (RCC Marker), which has reasonable specificity for papillary carcinomas [14, $18,19]$.

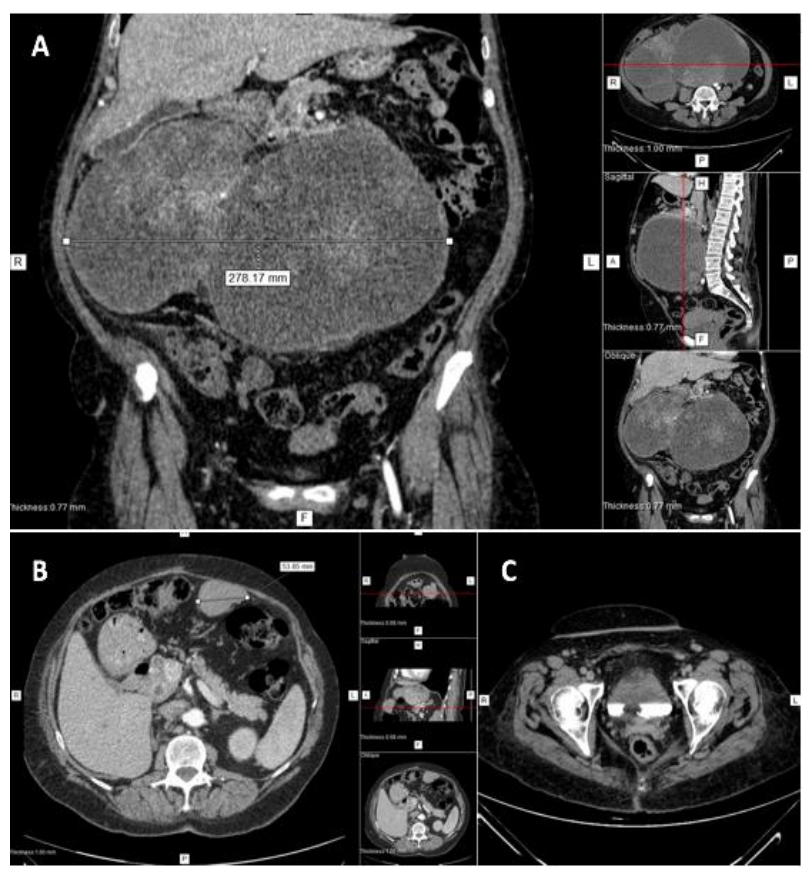

Figure 1: Computed tomography images with contrast. A) In coronal section detail (venous phase), multiloculated abdominal mass, septate with solid areas inside, as well as liquid content, measuring $278.17 \mathrm{~mm}$ in the latero-lateral axis, compressing adjacent structures. B) In detail, axial section (arterial phase) of a peritoneal mass with lobed and welldefined contours, adhered to the abdominal wall, measuring $53.85 \mathrm{~mm}$. C) Axial section of the pelvis (late phase), with emphasis on bladder filling failure, representing the metastatic vegetating lesion.

In the case presented, the immunoreactivity for racemase and vimentin were fundamental for the diagnosis of CCRP. Furthermore, the use of this technique proved to be a good strategy for confirming bladder metastasis. Other markers, such as p63, a gene that is a member of the p53 family, are not widely found in RCCs in general, being more specific for urothelial carcinoma [20]. It should also be mentioned that Yang et al. demonstrated a predominance in the expression of cytokeratin 7 (CK7) in type 1 carcinoma and, therefore, found that this would be another useful marker for the investigation of this tumor and the possibility of differentiating the two subtypes of PRCC [21]. 
The treatment of RCCs, in general, is done based on the size of the tumor, according to the TNM classification and location. In this case, the lesion was classified as T2. Therefore, radical laparoscopic nephrectomy was the main recommendation however, given the large volume of the mass, exceeding $20 \mathrm{~cm}$ in the transverse axis, open radical nephrectomy was indicated [17]. Concerning RCCs metastases, bladder involvement is a rare event since Saitoh et al. examined 1,451 autopsies in cases of $\mathrm{CRC}$, and only $2 \%$ presented metastasis to the bladder, one of which being isolated metastasis [22]. This event appears to be associated with advanced stages of the disease and a poor prognosis [23]. However, here, we present a case of metastases not only to the bladder but to the peritoneum and perigastric region (Figure 2). Metastases to the peritoneum are found in about $1-2 \%$ of cases, while for the gastric region, only $0.2-0.7 \%$ [24-27]. Metastases can be synchronous or metachronic. Metachronics are more common (77\%) [28]. The average time for metachronic bladder metastasis is 33 months [29].
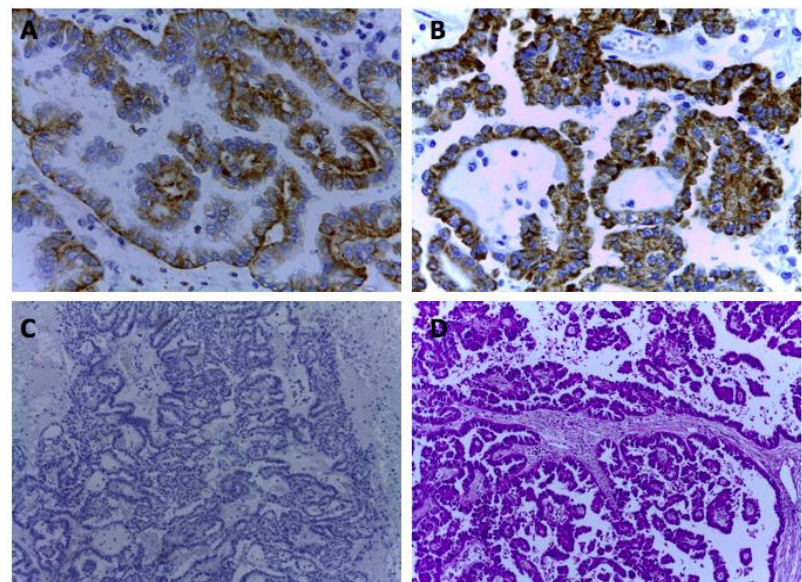

Figure 2: Fragment of the renal mass in the right kidney. A) Immunoreactivity for vimentin, $\mathbf{B}$ ) racemase and $\mathbf{C}$ ) immunonegativity for RCC Ma. D) Microscopy image showing papillae with a fibrous axis and neoplasic cells on the surface (H\&E, original magnification X10).

The main symptom that differentiates bladder metastasis from those that occur in other regions is related to the most visible hematuria. About $68 \%$ of patients with mechatronic metastasis have hematuria as the first indication of metastasis to the bladder [29]. This symptom was fundamental for the suspicion of bladder metastasis in our patient, months after surgery. The pathological mechanism of RCCs metastasis to the bladder is still uncertain, one of which is hematogenous dissemination due to the multiple cases of multiple metastases in distant organs. The other possible mechanism is through the urinary tract, which is implanted in the bladder. Such a mechanism is based on the observation of metastasis that did not penetrate the urothelium through microscopic analysis [30]. Finally, for cases where there is an invasive and deep metastasis in the musculature, an embolus mechanism through the lymphatic chain has been proposed [31].

We believe that our case, treat implantation in the bladder, given the superficiality and vegetative aspect of the lesion. The prognosis of RCC is considered good when the metastasis is located only in the bladder. Thus, it is possible to follow up without any systemic treatment after the removal of the metastatic lesion. Treatment options are limited since the neoplasia does not respond to chemotherapy and radiotherapy [31].
However, when metastasis occurs in other organs simultaneously with the involvement of the bladder, systemic treatment with immunotherapy is necessary. In summary, in the case discussed, at first, a large renal mass classified as a renal papillary carcinoma was found, which was promptly extracted through a radical nephrectomy, later, a solitary metastasis in the bladder was detected, being performed at transurethral resection. However, 11 months later, peritoneal metastasis was identified. Thus, the patient is currently awaiting the definition of new conduct.

\section{Conclusion}

In conclusion, we present a peculiar case of type 2 papillary renal carcinoma, due to the low incidence of the disease itself, its unusual size, despite being oligosymptomatic, in addition to the rare event of multiple metastases, both for the bladder and the omentum and perigastric region. We highlight the importance of immunohistochemistry, which was decisive for the diagnosis of metastatic lesions, as well as the imaging exams, which defined the best surgical approach.

\section{Acknowledgements}

None.

\section{Adherence to National and International Regulations}

Not applicable.

\section{Funding}

None.

\section{Availability of Data and Materials}

All data generated or analyzed during this study are included in this published article.

\section{Ethics Approval and Consent to Participate}

Written informed consent was obtained from the patient for participation in the study.

\section{Competing Interest}

None.

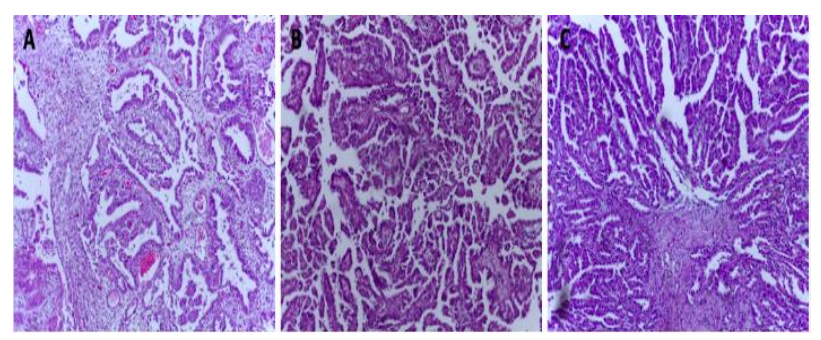

Supplementary Figures: Microscopy A) Bladder, B) epipplon and C) perigastric mass (H\&E, original magnification X10). 


\section{REFERENCES}

1. Courthod G, Tucci M, Di Maio M, Scagliotti GV (2015) Papillary renal cell carcinoma: A review of the current therapeutic landscape. Crit Rev Oncol Hematol 96: 100-112. [Crossref]

2. Klatte T, Pantuck AJ, Said JW, Seligson DB, Rao NP et al. (2009) Cytogenetic and molecular tumor profiling for type 1 and type 2 papillary renal cell carcinoma. Clin Cancer Res 15: 1162-1169. [Crossref]

3. Cohen HT, McGovern FJ (2005) Renal-cell carcinoma. N Engl J Med 353: 2477-2490. [Crossref]

4. Moch H, Cubilla AL, Humphrey PA, Reuter VE, Ulbright TM (2016) The 2016 WHO Classification of Tumours of the Urinary System and Male Genital Organs-Part A: Renal, Penile, and Testicular Tumours. Eur Urol 70: 93-105. [Crossref]

5. Muglia VF, Prando A (2015) Renal cell carcinoma: histological classification and correlation with imaging findings. Radiol Bras 48: 166-174. [Crossref]

6. Kovacs G, Akhtar M, Beckwith BJ, Bugert P, Cooper CS et al. (1997) The Heidelberg classification of renal cell tumours. J Pathol 183: 131133. [Crossref]

7. Kovacs G (1989) Papillary renal cell carcinoma. A morphologic and cytogenetic study of 11 cases. Am J Pathol 134: 27-34. [Crossref]

8. Petejova N, Martinek A (2016) Renal cell carcinoma: Review of etiology, pathophysiology and risk factors. Biomed Pap Med Fac Univ Palacky Olomouc Czech Repub 160: 183-194. [Crossref]

9. Palapattu GS, Kristo B, Rajfer J (2002) Paraneoplastic Syndromes in Urologic Malignancy: The Many Faces of Renal Cell Carcinoma. Rev Urol 4: 163-170. [Crossref]

10. Da Silva JL, Lacombe C, Bruneval P, Casadevall N, Leporrier M et al. (1990) Tumor cells are the site of erythropoietin synthesis in human renal cancers associated with polycythemia. Blood 75: 577-582. [Crossref]

11. Robson CJ, Churchill BM, Anderson W (1968) The results of radical nephrectomy for renal cell carcinoma. Trans Am Assoc Genitourin Surg 60: 122-129. [Crossref]

12. Mukamel E, deKernion JB (1988) Staging of Renal Cell Carcinoma. Aspiration Cytology in the Staging of Urological Cancer 209-214.

13. Thoenes W, Störkel S, Rumpelt HJ, Moll R, Baum HP et al. (1988) Chromophobe cell renal carcinoma and its variants--a report on 32 cases. J Pathol 155: 277-287. [Crossref]

14. Xia QY, Rao Q, Shen Q, Shi SS, Li L et al. (2013) Oncocytic papillary renal cell carcinoma: a clinicopathological study emphasizing distinct morphology, extended immunohistochemical profile and cytogenetic features. Int J Clin Exp Pathol 6: 1392-1399. [Crossref]

15. Delahunt B, Eble JN (1997) Papillary renal cell carcinoma: a clinicopathologic and immunohistochemical study of 105 tumors. Mod Pathol 10: 537-544. [Crossref]

16. Delahunt B, Eble JN, McCredie MR, Bethwaite PB, Stewart JH et al. (2001) Morphologic typing of papillary renal cell carcinoma: comparison of growth kinetics and patient survival in 66 cases. Hum Pathol 32: 590-595. [Crossref]

17. Jonasch E, Gao J, Rathmell WK (2014) Renal cell carcinoma. BMJ 349: g4797. [Crossref]

18. Liu K, Ren Y, Pang L, Qi Y, Jia W et al. (2015) Papillary renal cell carcinoma: a clinicopathological and whole-genome exon sequencing study. Int J Clin Exp Pathol 8: 8311-8335. [Crossref]

19. Pan CC, Chen PC, Ho DM (2004) The diagnostic utility of MOC31, BerEP4, RCC marker and CD10 in the classification of renal cell carcinoma and renal oncocytoma: an immunohistochemical analysis of 328 cases. Histopathology 45: 452-459. [Crossref]

20. Truong LD, Shen SS (2011) Immunohistochemical diagnosis of renal neoplasms. Arch Pathol Lab Med 135: 92-109. [Crossref]

21. Yang XJ, Tan MH, Kim HL, Ditlev JA, Betten MW et al. (2005) A molecular classification of papillary renal cell carcinoma. Cancer Res 65: 5628-5637. [Crossref]

22. Saitoh H (1981) Distant metastasis of renal adenocarcinoma. Cancer 48: 1487-1491. [Crossref]

23. Chinegwundoh FI, Khor T, Leedham PW (1997) Bladder metastasis from renal cell carcinoma. Br J Urol 79: 650-651. [Crossref]

24. Stavropoulos NJ, Deliveliotis C, Kouroupakis D, Demonakou M, Kastriotis J et al. (1995) Renal cell carcinoma presenting as a large abdominal mass with an extensive peritoneal metastasis. Urol Int 54 169-170. [Crossref]

25. Gonçalves MO, Benidir T, Erbano BO, Jung JE, de Almeida Luz M (2014) Peritoneal metastases from renal cell carcinoma: Images in urology. Can Urol Assoc J 8: E391-E392. [Crossref]

26. Uehara S, Yuasa T, Fujisaki J, Fujii Y, Yamamoto S et al. (2017) A case of gastric metastasis from renal cell cancer during the sequential targeted therapy. Int Cancer Conf J 6: 114-117. [Crossref]

27. Xu J, Latif S, Wei S (2012) Metastatic renal cell carcinoma presenting as gastric polyps: A case report and review of the literature. Int J Surg Case Rep 3: 601-604. [Crossref]

28. Matsumoto K, Hayakawa N, Nakamura S, Oya M (2015) Bladder metastasis from renal cell carcinoma: retrospective analysis of 65 reported cases. Clin Exp Metastasis 32: 135-141. [Crossref]

29. Gelister JS, Falzon M, Crawford R, Chapple CR, Hendry WF (1992) Urinary tract metastasis from renal carcinoma. Br J Urol 69: 250-252. [Crossref]

30. Remis RE, Halverstadt DB (1986) Metastatic renal cell carcinoma to the bladder: case report and review of the literature. J Urol 136: 1294 1296. [Crossref]

31. Uygur MC, Ozen HA, Sungur A, Remzi D (1994) A solitary and synchronous metastasis of renal cell carcinoma to the bladder. Int Urol Nephrol 26: 529-533. [Crossref] 